\title{
Upaya Meningkatkan Motivasi Dan Hasil Belajar Pada Tema 8 (Lingkungan Sahabat Kita) Peserta Didik Kelas V Semester Dua Tahun Pelajaran 2018/2019 Dengan Menerapkan Model "Listening Teams (Tim Pendengar) Di SD Negeri 7 Cakranegara"
}

\author{
Ni Nyoman Pujimulyati \\ Guru Kelas V SD Negeri 7 Cakranegara
}

\begin{abstract}
Abstrak. Penelitian ini bertujuan untuk mengetahui efektifitas penerapan pendekatan Saintifik model Listening Teams dalam upaya meningkatkan motivasi dan hasil belajar Peserta didik Kelas V SD Negeri 7 Cakranegara. Manfaat penelitian ini adalah mendorong peserta didik untuk mengembangkan ketrampilan belajar dalam kelompok (kognitif) dan bersosiolisasi dengan teman sebagai dalam proses pembelajaran di kelas senyatanya. Dan bagi guru meningkatkan pengembangan pendekatan dan model pembelajaran dengan penerapan saintifik Model Listening Teams dalam pembelajaran kerja kelompok (kooperatif). Penelitian ini dilaksanakan dua siklus, masing-masing siklus kegiatannya adalah; perencanaan, pelaksanaan, observasi dan refleksi. Hasil akhir tindakan pada siklus II pertemuan II menunjukkan bahwa hasil observasi guru memperoleh skor rata-rata $(4,64)$ dan hasil observasi Peserta didik mencapai skor rata-rata $(4,52)$. Sedangkan hasil belajar Peserta didik mencapai nilai rata-rata $(81,08)$, artinya indicator keberhasilan $(\geq 4,0)$ dan hasil belajar $(\geq 75,00)$ telah terlampaui. Karena indikator keberhasilan telah terbukti penelitian dinyatakan berhasil dan dihentikan pada siklus II.
\end{abstract}

Kata Kunci : Motivasi dan hasil Belajar-Model Listening Teams.

\section{PENDAHULUAN}

\section{Latar Belakang}

Salah satu model pembelajaran yang bisa membantu peserta didik untuk tetap konsentrasi dan focus dalam pembelajaran yaitu model pembelajaran "Listening Teams (Tim Pendengar)". Model pembelajaran ini masih tetap ada metode ceramah yang tujuannya yakni untuk membentuk kelompokkelompok yang mempunyai tugas dan tanggung jawab tertentu berkaitan dengan materi pelajaran. Model pembelajaran Listening Teams (tim pendengar) ini didukung oleh metode ceramah, diskusi kelompok, penugasan kelompok, yang hasilnya disampaikan didepan kelompok lain (didepan kelas). Apabila guru kelas mampu menerapkan model pembelajaran ini dengan baik maka motivasi dan hasil belajar peserta didik dapat ditingkatkan. Peningkatan motivasi dan hasil belajar peserta didik ini merupakan dampak positif dari penerapan model pembelajaran "Listening Teams (Tim Pendengar).

Di SD Negeri 7 Cakranegara khususnya pembelajaran di kelas $\mathrm{V}$ selama ini sudah menerapkan model pembelajaran yang mengarah pada pola pembelajaran peserta didik aktif. Ada beberapa peserta didik yang benar-benar aktif sesuai dengan harapan kurikulum 2013 (K.13). akan tetapi masih banyak pula peserta didik yang sikapnya acuh -tak acuh selama proses pembelajaran. Pada waktu proses pembelajaran ada yang tidur di tepat duduknya, ada yang main lempar kertas dengan temannya, dan ada juga yang keluar masuk kelas tanpa ijin. Kondisi ini telah mereduksi terjadinya ketidaknyamanan di kelas selama proses pembelajaran berlangsung. Sebagai dampak dari kurang seriusnya peserta didik dalam proses pembelajaran, maka motivasi dan hasil belajarnya pun dapat dikategorikan belum mencapai Kriteria Ketuntasan Minimal (KKM).

Rendahnya motivasi dan hasil belajar peserta didik disebabkan oleh beberapa faktor, diantaranya yaitu; 1) selama proses pembelajaran peserta didik kurang gairah belajar, kecendrungan hanya bermain-main, saling mengganggu, saling lempar kertas , dan seringnya keluar masuk kelas tanpa ijin, 2) 
karakteristik peserta didik masih rendah, tingkat pemahaman dalam menerima materi pelajaran masih rendah, dan 3) model pembelajaran maupun metode yang digunakan cenderung monoton dengan didominasi ceramah melulu. Setelah selesai ceramah peserta didik diberikan tugas begitu saja tanpa ada penjelasan dan pengawasan dari guru.

Banyak solusi yang bisa dilakukan oleh peneliti guna meningkatkan motivasi dan hasil belajar peserta didik. Diantara solusi yang baik itu menurut peneliti ada satu model pembelajaran yang mampu meningkatkan motivasi dan hasil belajar peserta didik kelas V semester dua tahun pelajaran 2018/2019 di SD Negeri 7 Cakranegara, yaitu dengan menerapkan model "Listening Teams (Tim Pendengar). Model pembelajaran ini sangat tepat bagi peserta didik ditingkat SD/MI karena memiliki beberapa keunggulan bila dibandingkan dengan model pembelajaran yang lain. Keunggulan model "Listening Teams (Tim Pendengar) adalah; 1) ketika guru sedang berceramah membahas tentang materi pelajaran, peserta didik cenderung memperhatikan dan menyimak dengan seksama, proses Tanya jawab berlangsung sangat antusias, 2) ketika peserta didik diberikan tugas secara berkelompok (diskusi kelompok) bisa berjalan lancer, dan 3) ketika masing-masing kelompok didepan kelas sangat antusias dan bersemangat.

Karena model "Listening Teams (Tim Pendengar)" memiliki beberapa keunggulan, untuk membuktikan kajian itu perlu diadakan Penelitian Tindakan Kelas (PTK) dengan judul "Upaya Meningkatkan Motivasi Dan Hasil Belajar Pada Tema 8 (Lingkungan Sahabat Kita) Peserta Didik Kelas V Semester Dua Tahun Pelajaran 2018/2019 dengan menerapkan model "Listening Teams (Tim Pendengar) di SD Negeri 7 Cakranegara".

\section{Rumusan Masalah}

"Bagaimana cara menerapkan model pembelajaran Listening Teams (Tim Pendengar) upaya meningkatkan motivasi dan hasil belajar pada tema 8 (Lingkungan Sahabat Kita) peserta didik kelas V semester dua tahun pelajaran 2018/2019 di SD Negeri 7 Cakranegara?".

\section{Tujuan Penelitian}

"untuk mengetahui efektifitas penerapatan model Listening Teams (Tim Pendengar) dalam upaya peningkatan motivasi dan hasil belajar peserta didik kelas V Semester dua tahun pelajaran 2018/2019 di SD Negeri 7 Cakranegara."

\section{Manfaat Penelitian}

- Bagi Peserta Didik : Mendorong peserta didik untuk mengembangkan ketrampilan belajar dalam kelompok (kognitif) dan bersosiolisasi dengan teman sebagai dalam proses pembelajaran di kelas senyatanya, dan Motivasi belajar bagi peserta didik dalam upaya pemahaman secara mandiri (eksplorasi) terhadap mata pelajaran Tematik sehingga hasil belajar dapat ditingkatkan.

- Bagi Guru: Meningkatkan pengembangan pendekatan dan model pembelajaran dengan penerapan model Listening Teams (Tim Pendengar) dalam pembelajaran kerja kelompok (kooperatif), dan Menumbuhkan aspirasi secara ilmiah dalam menjalankan profesi keguruan terutama dalam pengembangan keprofesian berkelanjutan (PKB) bagi guru Tematik.

\section{KAJIAN PUSTAKA \\ Motivasi}

Menurut Hoy dan Miskel (dalam Nurhayati:2006) motivation is defined as the complex of force, drives, needs, tension states, or orther internal psychological mechanism that star an maintain activity toward the achievement of personal goals. Dengan demikian motivasi dapat mempengaruhi prilaku seseorang dalam melakukan sesuatu, mempertahankan kegiatan yang telah ditetapkan terutama hasil belajar peserta didik.

Meskipun para ahli mendefinisikan dengan cara lain gaya yang berbeda, namun esensinya menuju kepada maksud yang sama, ialah bahwa motivasi itu merupakan:

1. Suatu kekuatan (power) atau tenaga (forces) atau daya (energy); atau

2. suatu keadaan yang kompleks (a complex state) dan kesiapsediaan (preparatory set) dalam diri individu (organism) untuk bergerak (to move, motion, motive) kearah 
tuntutan tertentu, baik disadari maupun tidak disadari.

Motivasi tersebut timbul dan tumbuh berkembang dengan jalan;

(1) Datang dari dalam diri individu itu sendiri (instrinsik); dan

(2) Datang dari lingkungan (ektrinsik)

(Syamsuddin Makmun,2005:37)

Berdasarkan konsep motivasi dari beberapa teori di atas, maka motivasi belajar dirumuskan sebagai kecenderungan peserta didik mengembangkan diri, dengan melakukan kegiatan belajar yang didukung oleh hasrat yang kuat untuk mencapai prestasi sebaik mungkin. Dan harus memperhatikan indicator motivasi sebagai berikut: 1) harapan sukses, 2) kerja keras, 3) tanggung jawab dan disiplin, 4) kemandirian dalam bertindak, 5) berani mengambil resiko, dan, 6) berusaha mencari cara-cara baru dalam memecahkan masalah sehingga akan meningkatkan keefektifitasan kondisi belajar.

Dalam kegiatan belajar mengajar, apabila ada seorang peserta didik, misalnya tidak berbuat sesuatu yang seharusnya dikerjakan, maka perlu diselidiki sebab-sebabnya. Sebabsebab itu bisaanya bermacam-macam, mungkin iya tidak senang, mungkin sakit, lapar, ada problem pribadi dan lain-lain. Hal ini berarti pada diri anak tidak terjadi perubahan energy, tidak terangsang efeksinya untuk melakukan sesuatu, karena tidak memiliki tujuan atau kebutuhan belajar. Keadaan semacam ini perlu dilakukan daya upaya yang dapat menemukan sebab musababnya dan kemudian mendorong seorang peserta didik itu mau melakukan pekerjaan yang seharusnya dilakukan, yakni belajar. Dengan kata lain peserta didik itu perlu diberikan rangsangan agar tumbuh motivasi pada dirinya. Atau singkatnya perlu diberikan motivasi. (Sudirman:1996:74-75)

\section{Hasil belajar}

Masalah evaluasi hasil belajar meliputi alat ukur yang digunakan, cara menggunakan, cara penilaian dan evaluasinya (Harus Rasid dan Mansur, 2008:9). Evaluasi hasil belajar yang berhubungan dengan tugas guru rutin dilakukan evaluasi hasil, yang juga dijadikan umpan balik, evaluasi hasil bertujuan menilai apakah hasil belajar dicapai sesuai dengan tujuan (Lukmanul Hakim, 2008:165). Pakar pendidikan lain mendefinisikan bahwa yang dimaksud hasil belajar adalah perubahan perilaku secara keseluruhan bukan salah satu aspek potensi kemanusiaan saja (Supriyono, 2009:19). Berbeda dengan pendapatnya Bloom (Dalam Sumiati danAska, 2008). Hasil belajar mencakup kemampuan kognitif, afektif, dan psikomotorik. Jadi pendapat ini mengisyaratkan bahwa haasil belajar peserta didik harus diukur dengan tes tertulis, tes sikap, dan kemampuan skil secara nyata selama proses pembelajaran di kelas senyatanya.

Dalam penelitian ini yang dimaksud dengan hasil belajar adalah tes ulangan harian yang dilaksanakan secara tertulis pada akhir pembelajaran dan nilai hasil diskusi kelompok yang dinilai secara perorangan.

\section{Model Listening Teams (Tim Pendengar)}

Pengertian operasional dari Listening Team adalah suatu usaha untuk memperoleh pemahaman akan hakikat dari suatu konsep atau prinsip atau keterampilan tertentu melalui proses kegiatan atau latihan yang melibatkan indera pendengaran. Penggunaan Listening Team dalam pembelajaran yang lebih menekankan pada pengoptimalan indera pendengaran peserta didik (di samping indera lainnya), diharapkan secara tepat dapat mendorong peserta didik agar tetap fokus dan siap siaga selama proses pembelajaran berlangsung. Strategi ini membantu peserta didik untuk tetap berkonsentrasi dan terfokus dalam pelajaran yang menggunakan metode ceramah. Metode ceramah dapat diartikan sebagai cara menyajikan pelajaran melalui penuturan secara lisan atau penjelasan langsung kepada sekelompok peserta didik. Strategi Listening Team ini bertujuan membentuk kelompok yang mempunyai tugas atau tanggung jawab tertentu berkaitan dengan materi pelajaran sehingga akan diperoleh partisipasi aktif peserta didik selama proses pembelajaran berlangsung. Yang mana diawali dengan pemaparan pembelajaran oleh guru. Selanjutnya guru membagi kelas menjadi kelompok-kelompok. Setiap kelompok mempunyai peran masing-masing. Misal, 40 
orang dalam suatu kelas dibagi menjadi 4 kelompok.

\section{Langkah-langkah pembelajaran Listening}

Teams (Tim Pendengar)

1. Bagilah peserta didik menjadi empat kelompok, masing-masing kelompok mendapat salah satu dari tugas dari guru.

2. Sampaikan materi pelajaran dengan metode ceramah yang didasarkan pada sesi tatap muka. Setelah selesai, berilah kesempatan kepada masing-masing kelompok untuk menyelesaikan tugas mereka dan beberapa saat untuk mengomentari tugas-tugas mereka.

3. Mintalah masing-masing kelompok untuk menyampaikan hasil dari tugas mereka. Baik itu akan menimbulkan kegiatan bertanya, sepakat, dan sebagainya. Guru hendaknya memperoleh partisipasi peserta didik dari pada yang pernah guru bayangkan.

4. Beri klarifikasi secukupnya.

Modifikasi :

a. Jika jumlah peserta didik banyak, buatlah kelompok ganda artinya terdapat 2 kelompok sebagai penanya dan begitu pula pada kelompok lainnya.

b. Bisa juga dawali dengan tugas individual.

5. Pembelajaran diakhiri dengan penyampaian berbagai kata kunci atau konsep yang telah dikembangkan oleh peserta didik dalam diskusi.

\section{Kerangka Konseptual}

Kerangka konseptual ini menggambarkan hubungan antara variabel tindakan dan variabel harapan. Variabel tindakan yaitu mengoptimalkan penerapan Listening Team, sedangkan variabel harapan adalah meningkatkan motivasi dan hasil belajar.

\section{Hipotesis Tindakan}

"Jika penerapan Model Listening Teams (Tim Pendengar) dilaksanakan secara optimal maka motivasi dan hasil belajar peserta didik kelas V Semester dua tahun pelajaran 2018/2019 dapat ditingkatkan".

\section{PROSEDUR PENELITIAN}

\section{Setting Penelitian}

Penelitian tindakan kelas (PTK) ini akan dilaksanakan di kelas V SD Negeri 7
Cakranegara Semester dua tahun pelajaran 2018/2019, dengan jumlah peserta didik sebanyak 38 orang peserta didik.

\section{Faktor yang Diteliti}

- Faktor Guru: yaitu dengan mengganti cara guru membuat Rencana Pelaksanaan Pembelajaran (RPP) dan pelaksanaannya dalam pembelajaran di kelas senyatanya dengan menerapkan model Listening Teams (Tim Pendengar) dalam upaya meningkatkan motivasi dan hasil belajar peserta didik Kelas V SD Negeri 7 Cakranegara.

- Faktor Peserta Didik: yaitu peningkatan motivasi dan hasil belajar yang terlihat pada perilaku peserta didik selama diskusi kelompok, yang berdampak pada peningkatan motivasi dan hasil belajar peserta didik Kelas V Semester dua Tahun pelajaran 2018/2019 di SD Negeri 7 Cakranegara.

\section{Rencana Tindakan}

Tindakan nyata yang dilakukan oleh guru selaku peneliti adalah dengan menggunakan siklus. Gambaran siklus dalam penelitian ini adalah sebagai berikut:

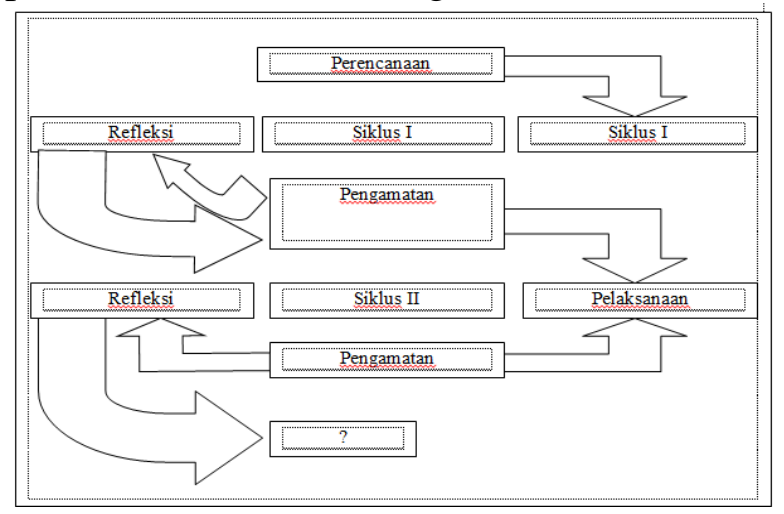

Setiap siklus selama penelitian ini berisi 4 (empat) tahapan yaitu: 1) Perencanaan (Planning), 2) Pelaksanaan (Action), 3) Observasi (Observation), dan 4) Refleksi (Reflection).

\section{Siklus Tindakan}

\section{SIKLUS I}

\section{Tahap Perencanaan (Planning)}

Pada tahapan ini guru selaku peneliti melakukan kegiatan-kegiatan sebagai berikut:

1. Menyusun Rencana Pelaksanaan Pembelajaran (RPP) dengan skenario sesuai dengan aturan main model 
pembelajaran Listening Teams (Tim Pendengar)

2. Menyiapkan sumber, bahan, dan semua alat yang digunakan dalam penelitian.

3. Menyusun/membuat lembar observasi guru dan lembar observasi peserta didik.

4. Menyusun alat evaluasi.

Tahap Pelaksanaan (Action)

\section{Pertemuan I}

1. Peserta didik berjumlah 38 orang yang kemudian dibagi menjadi 6 (enam) kelompok. Masing-masing kelompok beranggotakan sebanyak 6 dan 7 orang peserta didik..

2. Guru memberikan kesempatan kepada masing-masing kelompok untuk mengerjakan tugas yang sudah diberikan pada saat sesi tatap muka.

3. Hasil diskusi yang dillakukan akan dikerjakan secara individual

\section{Pertemuan II}

1. Setelah masing-masing kelompok menyelesaikan diskusinya, kemudian secara begiliran masing-masing kelompok mempresentasikan hasil dari diskusi yang telah dilakukan sebelumnya di depan kelas.

2. Setelah semua kelompok selesai mempresentasikan hasil diskusinya di depan kelas, kemudian guru memberi klarifikasi secukupnya atas hasil diskusi selama proses pembelajaran berlangsung.

3. Pembelajaran diakhiri dengan penyampaian berbagai kata kunci atau konsep yang telah dikembangkan oleh peserta didik dalam diskusi.

4. Tes Tertulis

\section{Tahap Observasi (Observation)}

- Observasi guru : Dilakukan oleh pembimbing/observer sekaligus sebagai pembimbing guru dalam melaksanakan Penelitian Tindakan Kelas (PTK).

- Observasi Peserta Didik : Dilaksanakan oleh guru mata pelajaran sekaligus sebagai peneliti dalam Penelitian Tindakan Kelas (PTK) pada kegiatan diskusi kelompok.

\section{4). Tahap Refleksi (Reflection)}

1. Renungan hasil perolehan data

2. Pengolahan dan analisa data hasil penelitian
3. Mencocokkan hasil analisa data dengan indikator keberhasilan

4. Rencana perbaikan dan tindak lanjut

\section{SIKLUS II}

Pada siklus ini semua kegiatan dan tahapan selama penelitian adalah sama, sifatnya mengulang dan memperbaiki terhadap tindakan yang masih memerlukan penyempurnaan dan pembenaran sebagaimana mestinya.

\section{Data dan Cara Pengambilannya. Sumber Data}

Yang menjadi sumber data dalam penelitian tindakan kelas (PTK) ini adalah semua peserta didik kelas V Semester dua tahun pelajaran 2018/2019 di SD Negeri 7 Cakranegara dan peneliti.

\section{Jenis Data}

- Jenis data yang berasal dari guru selaku peneliti

1). Data tentang Rencana Pelaksanaan Pembelajaran (RPP)

2). Data Pelaksanaan Pembelajaran

- Jenis data yang berasal dari peserta didik :

1). Data kemajuan motivasi belajar

2). Data hasil diskusi kelompok

3). Data hasil belajar

\section{Cara Pengambilan data}

- Data kegiatan pembelajaran diambil dari RPP yang dibuat oleh guru dan lembar observasi pelaksanaan metode pembelajaran model Listening Teams (Tim Pendengar)

- Data kemajuan motivasi belajar; diambil dari lembar observasi selama diskusi kelompok.

- Data kemajuan hasil belajar; diambil dari laporan individu hasil diskusi kelompok dan hasil tes tertulis yang dilaksanakan pada akhir proses pembelajaran

Indikator Keberhasilan dan Teknik analisa data

\section{Teknik analisa data}

Untuk menganalisis data akan dilakukan melalui analisis deskriptif kuantitatif melalui pendataan, analisis dan pembahasan terhadap data yang diperoleh dengan mencocokkan tingkat keoptimalan 
terhadap capaian indikator keberhasilan yang ada.

\section{Indikator Keberhasilan}

- Guru telah dinyatakan berhasil melaksanakan proses pembelajaran dengan model Listening Teams (Tim Pendengar), bila telah mencapai skor rata-rata $\geq 4,00$ (kategori baik)

- Motivasi belajar peserta didik kelas V dinyatakan telah meningkat jika $85 \%$ dari jumlah peserta didik telah memperoleh skor rata-rata $\geq 4,0$ dan hasil belajar dinyatakan telah meningkat jika $85 \%$ dari jumlah peserta didik memperoleh nilai rata-rata $\geq 75,00$ (sesuai KKM).

\section{HASIL DAN PEMBAHASAN}

\section{DESKRIPSI SIKLUS I}

\section{Tahap Perencanaan}

Pada tahapan ini yang telah dilakukan oleh guru selaku peneliti adalah; 1) menyusun RPP dengan skenario pembelajaran model Listening Teams (Tim Pendengar), 2) telah berhasil menyiapkan alat, sumber, bahan yang diperlukan dalam penelitian, 3) berhasil menyusun instrument observasi guru dan instrument observasi peserta didik, dan 4) menyusun alat evaluasi.

\section{Tahap Pelaksanaan}

\section{Pertemuan I}

1. Peserta didik berjumlah 38 orang yang kemudian dibagi menjadi 6 (enam) kelompok. Masing-masing kelompok beranggotakan sebanyak 6 dan 7 orang peserta didik..

2. Guru memberikan kesempatan kepada masing-masing kelompok untuk mengerjakan tugas yang sudah diberikan pada saat sesi tatap muka.

3. Hasil diskusi yang dillakukan akan dikerjakan secara individual

\section{Pertemuan II}

4. Setelah masing-masing kelompok menyelesaikan diskusinya, kemudian secara begiliran masing-masing kelompok mempresentasikan hasil dari diskusi yang telah dilakukan sebelumnya di depan kelas.

5. Setelah semua kelompok selesai mempresentasikan hasil diskusinya di depan kelas, kemudian guru memberi klarifikasi secukupnya atas hasil diskusi selama proses pembelajaran berlangsung.
6. Pembelajaran diakhiri dengan penyampaian berbagai kata kunci atau konsep yang telah dikembangkan oleh peserta didik dalam diskusi.

7. Tes Tertulis

\section{Tahap Observasi}

Observasi guru memperoleh skor ratarata pertemuan I $(3,21)$ dan pertemuan II $(3,43)$, observasi peserta didik memperoleh skor rata-rata pertemuan I $(3,23)$ dan pertemuan II $(3,48)$. Perolehan hasil belajar dalam bentuk tugas individual dan tes tertulis adalah $(69,34)$ dan $(68,05)$.

\section{Tahap Refleksi}

1. Renungan data hasil perolehan data pada siklus I

2. Pengolahan data hasil observasi guru, peserta didik dan tes tertulis.

3. Mencocokkan hasil yang ada dengan Indikator keberhasilan.

4. Merencanakan perbaikan terhadap jenis tindakan yang menyebabkan belum tuntas Indikator keberhasilan. Oleh karena Indikator keberhasilan belum terbukti maka penelitian dilanjutkan ke siklus II.

\section{DESKRIPSI SIKLUS II \\ Tahap Perencanaan}

Pada tahapan ini jenis kegiatan yang dilakukan masih mengacu pada kegiatan siklus I, bedanya hanya terjadi perbaikan seperlunya yaitu: 1) penyusunan RPP dengan mengacu pada pendekatan saintifik model Listening Teams (Tim Pendengar) dan diskusi kelompok dan penyempurnaan pada bagian skenario pembelajaran, 2) menyiapkan alat, sumber, bahan yang diperlukan dalam proses tindakan dikelas senyatanyan, 3) menyiapkan lembar observasi guru dan lembar observasi peserta didik sebagaimana pada siklus I, 4) menyiapkan alat evaluasi sebagaimana yang telah dibuat pada siklus I.

\section{Tahap Pelaksanaan}

Secara umum tahapan pelaksanaan proses pembelajaran pada siklus II ini masih mengacu pada pelaksanaan proses pembelajaran sebelumnya. Pemecahan yang dilakukan pada proses pembelajaran ini adalah: 1) pelaksanaan proses diskusi kelompok kecil lebih dioptimalkan, 2) pelaksanaan pembimbingan kelompok 
sekaligus observasi peserta didik lebih di efektifkan. Utamanya pengamatan peserta didik yang aktif, yang kurang aktif, peserta didik yang tidak aktif, dengan harapan proses analisa data lebih signifikan, 3) laporan hasil kerja kelompok yang dibuat secara individu yang dipresentasikan dikelas difokuskan, dan 4) pelaksanaan tes tertulis sebagai perwujudan dari peningkatan hasil belajar peserta didik lebih diperketat.

\section{Tahap Observasi}

Observasi guru memperoleh skor ratarata pertemuan I $(4,29)$ dan pertemuan II $(4,64)$, observasi peserta didik memperoleh skor rata-rata pertemuan I $(4,18)$ dan pertemuan II $(4,52)$. Perolehan hasil belajar dalam bentuk tugas individual dan tes tertulis adalah $(77,26)$ dan $(81,08)$.

\section{Tahap Refleksi}

1. Renungan atas perolehan data hasil observasi guru, observasi peserta didik, dan hasil tes tertulis sebagai wujud dari peningkatan motivasi dan hasil belajar peserta didik di kelas senyatanya.

2. Pengolahan data hasil observasi guru, observasi peserta didik, presentasi peserta didik dan tes tertulis

3. Mencocokkan perolehan data hasil tindakan dengan Indikator keberhasilan yang telah ditetapkan.

4. Guru memberikan hadiah/reward kepada semua peserta didik kelas $\mathrm{V}$ atas keberhasilannya dalam upaya meningkatkan motivasi belajar yang berdampak terhadap perolehan hasil belajar sesuai dengan KKM yang telah ditetapkan.

\section{Pembahasan \\ SIKLUS I \\ Tahap Perencanaan}

Peneliti menyusun RPP dengan skenario penerapan model Listening Teams (Tim Pendengar), menyiapkan alat, sumber, bahan yang diperlukan dalam proses pembelajaran, menyiapkan instrument observasi guru maupun instrument observasi peserta didik. Ada kendala yang dihadapi selama persiapan alat dan bahan pembelajaran, tetapi setelah meminta petunjuk kepada pembimbing kendala yang dihadapi pun dapat diatasi dengan baik.

\section{Tahap Pelaksanaan \\ Pertemuan I}

1. Peserta didik berjumlah 38 orang yang kemudian dibagi menjadi 6 (enam) kelompok. Masing-masing kelompok beranggotakan sebanyak 6 dan 7 orang peserta didik..

2. Guru memberikan kesempatan kepada masing-masing kelompok untuk mengerjakan tugas yang sudah diberikan pada saat sesi tatap muka.

3. Hasil diskusi yang dillakukan akan dikerjakan secara individual

\section{Pertemuan II}

4. Setelah masing-masing kelompok menyelesaikan diskusinya, kemudian secara begiliran masing-masing kelompok mempresentasikan hasil dari diskusi yang telah dilakukan sebelumnya di depan kelas.

5. Setelah semua kelompok selesai mempresentasikan hasil diskusinya di depan kelas, kemudian guru memberi klarifikasi secukupnya atas hasil diskusi selama proses pembelajaran berlangsung.

6. Pembelajaran diakhiri dengan penyampaian berbagai kata kunci atau konsep yang telah dikembangkan oleh peserta didik dalam diskusi.

7. Tes Tertulis

\section{Tahap Observasi}

Observasi guru memperoleh skor ratarata pertemuan I $(3,21)$ dan pertemuan II $(3,43)$, hasil observasi peserta didik dalam upaya peningkatan motivasi dan hasil belajar Tematik peserta didik kelas V Semester dua tahun pelajaran 2018/2019 di SD Negeri 7 Cakranegara diperoleh skor rata-rata pertemuan I $(3,23)$ dan pertemuan II $(3,48)$. Dari hasil tugas dan tes tertulis yang materinya hanya sekitar yang diajarkan pada saat itu juga, diperoleh nilai rata-rata $(69,34)$ dan $(68,05)$ kategori cukup.

\section{Tahap Refleksi}

Hasil analisa data peningkatan motivasi belajar pada siklus I pertemuan II ini $(3,43)$ sedangkan yang diminta dalam Indikator keberhasilan $(\geq 4,0)$, ini artinya belum berhasil. Karena Indikator keberhasilan belum tercapai, penelitian tindakan kelas (PTK) dilanjutkan ke siklus II dengan harapan 
optimalisasi penerapan strategi pembelajaran dengan pendekatan saintifik model Listening Teams (Tim Pendengar) dapat meningkatkan motivasi belajar Tematik peserta didik kelas V Semester dua tahun pelajaran 2018/2019 di SD Negeri 7 Cakranegara.

\section{SIKLUS II}

\section{Tahap Perencanaan}

Peneliti menyusun Rencana Pelaksanaan Pembelajaran (RPP) dengan memperhatikan kesalahan-kesalahan pada siklus I. peneliti lebih memfokuskan tentang Rencana strategi jitu sehingga proses pembelajaran dengan pendekatan Saintifik model Listening Teams (Tim Pendengar) dapat terelaisasi dengan baik, karenanya dalam penyusunan skenario benar-benar dirinci dari tiap aspek pada proses pembelajaran dengan model Listening Teams (Tim Pendengar). Sebelum proses pembelajaran dilaksanakan, peneliti menyiapkan semua alat, bahan, dan segala sesuatunya sehingga dalam pelaksanaan proses pembelajaran berjalan sesuai dengan skenario yang telah direncanakan. Agar proses pembelajaran dapat teratasi maka peneliti juga menyiapkan lembar observasi guru dan lembar observasi peserta didik sebagai tolak ukur ketercapaian peningkatan motivasi dan hasil belajar peserta didik kelas V SD Negeri 7 Cakranegara.

\section{Tahap Pelaksanaan}

Pada tahap pelaksanaan di siklus II ini pada dasarnya masih mengacu pada pelaksanaan siklus I, yaitu penerapan pendekatan Saintifik model Listening Teams (Tim Pendengar) dan. Bedanya pada siklus ini lebih dioptimalkan.

\section{Tahap Observasi}

Pada siklus II ini hasil skor rata-rata pertemuan I $(4,29)$ dan pertemuan II $(4,64)$, upaya meningkatkan motivasi belajar Tematik peserta didik kelas V Semester dua tahun pelajaran 2018/2019 di SD Negeri 7 Cakranegara diperoleh skor rata-rata pertemuan I $(4,18)$ dan pertemuan II $(4,52)$, dampak nyata dari meningkatnya motivasi belajar adalah hasil belajar juga meningkat, dari data hasil perolehan nilai rata-rata tugas dan tes tertulis adalah $(77,26)$ dan $(81,08)$ sementara pada siklus sebelumnya hanya
$(69,34)$ dan $(68,05)$ berarti mengalami peningkatan yang signifikan.

\section{Tahap Refleksi}

Hasil analisa data peningkatan motivasi dan hasil belajar peserta didik pada siklus II pertemuan II adalah (4,52) dan $(81,08)$ sedangkan Indikator keberhasilan $(\geq 4,0)$ dan $\geq 75,00$. Ini artinya pada siklus II hasilnya telah melampaui Indikator keberhasilan yang telah di tetapkan. Karena Indikator keberhasilan telah terbukti, maka tidak perlu ada upaya perbaikan dan penyempurnaan. Pendekatan Saintifik model Listening Teams (Tim Pendengar) telah mampu meningkatkan motivasi dan hasil belajar peserta didik yang ditandai dengan tercapainya Indikator keberhasilan dan terjadinya peningkatan hasil belajar peserta didik. "Penelitian Tindakan Kelas (PTK) dihentikan pada siklus II dengan hasil memuaskan."

\section{SIMPULAN}

Data komulatif dari hasil penelitian tindakan kelas (PTK) dari siklus I ke Siklus II adalah sebagai berikut:

\begin{tabular}{|c|l|c|c|c|c|c|c|}
\hline \multirow{2}{*}{ No } & \multirow{2}{*}{\begin{tabular}{c}
\multirow{2}{*}{ Jenis Kegiatan } \\
Indikator
\end{tabular}} & \multicolumn{2}{|c|}{ Siklus I } & \multicolumn{2}{|c|}{ Siklus II } & \multirow{2}{*}{ Ket } \\
\cline { 4 - 7 } & & & I & II & I & II & \\
\hline 1. & Observasiasi Guru & $\geq 4,00$ & 3,21 & 3,43 & 4,29 & 4,64 & Tuntas \\
\hline 2. & Observasi Peserta didik & $\geq 4,00$ & 3,23 & 3,48 & 4,18 & 4,52 & Tuntas \\
\hline 3. & Tugas Individual & $\geq 75,00$ & 69,34 & - & 77,26 & - & Tuntas \\
\hline 4. & Tes tertulis & $\geq 75,00$ & - & 68,05 & - & $81,-08$ & Tuntas \\
\hline
\end{tabular}

Penerapan pendekatan Saintifik model Listening Teams (Tim Pendengar) sangat efektif upaya untuk meningkatkan motivasi dan hasil belajar peserta didik kelas V Semester dua tahun pelajaran 2018/2019 di SD Negeri 7 Cakranegara. Fakta telah menunjukkan perolehan rata-rata skor motivasi belajar peserta didik pada siklus I ke siklus II sudah melampaui Indikator keberhasilan yang ditetapkan. Penelitian dinyatakan "berhasil" dan dihentikan pada siklus II.

\section{Saran-Saran}

Disarankan kepada guru sejawat untuk melaksanakan Penelitian Tindakan Kelas (PTK) dalam upaya untuk meningkatkan motivasi dan hasil belajar peserta didik sesuai dengan mata pelajaran masing-masing.

Disarankan kepada para semua peserta didik kelas V SD Negeri 7 Cakranegara untuk membisaakan belajar dengan pendekatan 
yang kontekstual utamanya strategi yang mampu membangkitkan motivasi belajar peserta didik yang dampaknya hasil belajar dapat ditingkatkan seperti yang diharapkan.

\section{DAFTAR PUSTAKA}

Anonim, 2018 , dalam http://dadangjsn.blogspot.com/2014/ 06/pengertiandefinisi-pendekatansaintifik.html, Tanggal 28 Juli 2018, Pukul 15.32 Wita

Arikunto, s. 2009, Penelitian Tindakan Kelas, Jakarta : Bumi Aksara.

Harun Rasyid dan Mansur, 2008, Penilaian Hasil Belajar, Bandung : CV Wacana Prima.

Lukmanul A, 2008, Perencanaan Pembelajaran, Bandung : CV Wacana Prima.

Mukhtar, 2003, Prosedur Penilaian, Jakarta : Rineka Cipta.

Nurhadi, 2003, Yasin ,B dan Sendule.A, 2003, Kontekstual dan Penerapannya dalam KBK, Malang : Unitipetas Negeri Malang.

Rahmadanni Pohan, 2018, Strategi pembelajaran Listening team, dalam http://rahmadannipohan.blogspot.co $\mathrm{m} / 2012 / 05 /$ strategi-pembelajaranlistening-team.html, diambil tanggal 28 Januari 2019, pada pukul 15.40 wita

Robert E Slavin, 2010, Cooperative Learning Teori, riset dan Praktik, Bandung : Nusa Media.

Sardiman, 2007, Indikator Dan Motivasi Belajar Mengajar, Jakarta : Raja Grafindo Perkasa.

Supriono, 2009, Cooperative Learning Teori dan Aplikasi PAIKEM, Yogyakarta : Pustaka Pelajar.

Permen 81A Tahun 2013 Tentang Implementasi Kurikulum 2013

Susilawati, E., Sarnita, F., Gumilar, S., Erwinsyah, A., Utami, L., \& Amiruddin, A. (2019, November). Using inductive approach (IA) to enhance students' critical thinking (CT) skills. In Journal of Physics: Conference Series (Vol. 1280, No. 5, p. 052035). IOP Publishing. 